\title{
Polyvariance of Floral Organogenesis of Syringa josikaea Jacq. (Oleaceae) in the Conditions of the Arctic Urbanized Territory
}

\author{
Natalia V. Vasilevskaya, Darya A. Morozova \\ Murmansk Arctic State University, Russia \\ Email: n.v.vasilevskaya@gmail.com
}

\begin{abstract}
This article presents the data of the morpho-physiological analysis of the reproductive buds of Syringa josikaea Jacq. that was introduced in the city of Murmansk located in the Far North of Russia. It is shown, that in the conditions of the Arctic climate, the beginning of differentiation of the axes of the inflorescences and the organogenesis of flowers can occur both: a year before blooming and in the spring period, two-three months before its beginning. The polyvariance of the floral organogenesis in cenopopulations of the $S$. josikaea of Murmansk city has been revealed. Experimental data on the polyvariance of the organogenesis of reproductive organs of lilac are first obtained in the Arctic urbanized territory.
\end{abstract}

Keywords: Syringa josikaea Jacq., floral organogenesis, urbanized territories, Arctic

\section{Introduction}

When plants are introduced into the new environment, the study of morphogenesis is of particular importance, since the biological rhythm of development largely determines the degree of their adaptability to local climate [14]. It is known, that the time and the rate of the initiation of generative buds vary, depending on the climatic conditions of the region, the rhythms of plant development and their winter hardiness. Moreover, frost-resistant species are characterized by early terms of the basic phenophases and the beginning of defferentiation of the reproductive organs [3]. Plants, which were successfully introduced in the northern regions, have a more intensive differentiation of the flowers.

The genus Syringa L. is widely spread in various regions of the world due to its decorativeness, while the data on the number of species are contradictory [16], [27]. Some researchers believe that there are 40 species of lilacs spreading both in Europe and in Asia [27]. According to other sources, the genus Syringa L. includes 27 species, 25 of which come from Asia and only 2 from Europe [16]. One of the European species is Syringa josikaea Jack. Information on the floral organogenesis and cytoembryology of species and cultivars of lilacs in the scientific literature is rather limited [4], [12], [13], [21], [34], the phenology of their flowering is studied much better [1], [2], [6], [23], [30], [31]. In recent years active research has begun on reproductive development of the most promising cultivars of S. vulgaris [12], [13], [21], similar studies on S. josikaea are few [18], [22], [29]. However, it is the S. josikaea, that has been successfully introduced in the urbanized territories of the Euro-Arctic region, while S. vulgaris does not form reproductive organs in the conditions of the polar day and does not bloom.

The purpose of research is to study the dynamics of floral organogenesis of Syringa josikaea Jacq. in the conditions of the arctic urbanized territory (on the example of the city of Murmansk).

The research was conducted in Murmansk, the world's largest non - freezing port beyond the Arctic Circle $\left(68^{\circ} 58^{\prime} \mathrm{N}, 33^{\circ} 4^{\prime} \mathrm{E}\right)$. Murmansk is situated on four terraces and stretched along the Kola Bay of the Barents Sea for $25 \mathrm{~km}$, with separate districts, divided by hills and areas of natural vegetation. The city is in the Atlantic-Arctic zone of temperate climate [32]. Murmansk climate is formed by the proximity of the Barents Sea, whose influence is enhanced by the warm North Atlantic Current. The average temperature in January - February is minus $10^{\circ} \mathrm{C}$. Summer is cold, the average temperature in July is plus $12{ }^{\circ} \mathrm{C}$ [9]. Most of the precipitation in Murmansk, approximately $500 \mathrm{~mm}$ per year, falls from June to September. The snow cover keeps in the city average 210 days and snow is melting in May. The wind is monsoonal - in the winter, the southern winds prevail, in the summer - the northern winds. The polar night begins on 29 of November and ends on 13 of January (44 days), the polar day - from 22 of May to 22 of July (62 days) [32]. The duration of vegetative period is approximately $120-130$ days. 
The main sources of pollution of the city's atmosphere are the Murmansk boiler houses, operating on fuel oil, the Murmansk Commercial seaport, plant for the incineration of solid domestic waste and automobile transport.

\section{Methodology}

\subsection{Syringa josikaea Jacq}

The subject of the study is Syringa josikaea Jacq. (Oleaceae Hoffmgg \& Link).

S. josikaea is an endemic shrub of the Western Carpathians, a relic of Tertiary period, with a narrow range and endangered [16], [17]. Several local populations exist here on small plots in valleys along creeks, often represented by only several instances and separated by large distances. Currently, in natural conditions, S. josikaea are very rare, there are only 25 small populations in two disjunctive regions - the Ukrainian Carpathians and the Apuseni mountains on the territory of Romania [7], [17].

S. josikaea is a fast - growing species, highly resistant to drought and frost. Successful introduction in the northern regions of the European part of Russia is determined by high ecological plasticity [8], [9]. At introduction it is one of the most winter-hardy species in comparison with other representatives of the genus Syringa L. [19]. S. josikaea is well adapted to urban conditions, resistant to atmospheric pollution [23], [26]. Due to high decorativeness, resistance and success of reproduction, Hungarian lilac is on one of the first places in the range of bushes for landscaping of the urbanized territories of Far North of Russia [11]. The seedlings of Hungarian lilac were first brought to the Polar-Alpine Botanical Garden (Kirovsk, Murmansk region) in 1936 from the Botanical Garden of Leningrad [11] and already in $1940 S$. josikaea has been planted in the cities of Murmansk and Monchegorsk. Currently, the share of this species in green spaces of Murmansk is $28 \%$ [10].

Generative buds of $S$. josikaea of mixed type [14], in addition to the inflorescence, 2- 4 pairs of leaves are laid in them. This species is characterized by the formation of generative buds both in the year, preceding bloom, and during it, which explains the longer blossoming time, compared to other species of lilacs $[22]$.

\subsection{Location of Experimental Sites}

Experimental sites in the cenopopulations of $S$. josikaea in the territory of the city of Murmansk were formed during vegetation period of 2014, they were located from the north to the south (Fig. 1) and differed in altitude above sea level, microclimatic conditions, anthropogenic load: experimental plot 1 (P1) - square near the shopping center "Mir" (Leninsky district); $\mathrm{P}_{2}$ - square on the Leningradskaya Street (Oktyabrsky district); $\mathrm{P}_{3}$ - square near the bus stop "Autopark" and $\mathrm{P}_{4}-$ square near the bus stop "Shevchenko Street" (Pervomaisky district). All experimental plots are located in areas with increased anthropogenic load: $\mathrm{P}_{1}$ ("Mir") is not far from the industrial zone; $\mathrm{P}_{2}$ (Leningradskaya Street) is close to the railway and the Murmansk Commercial seaport, where the coal is transshipped by the opened method; $\mathrm{P}_{3}$ (Autopark) and $\mathrm{P}_{4}$ (Shevchenko street) are located in the zones of intensive traffic. As a control site, we selected green plantations in Safonovo village, $19 \mathrm{~km}$ north of Murmansk. This park is located on the shore of the Kola Gulf, far from roads and industrial productions.

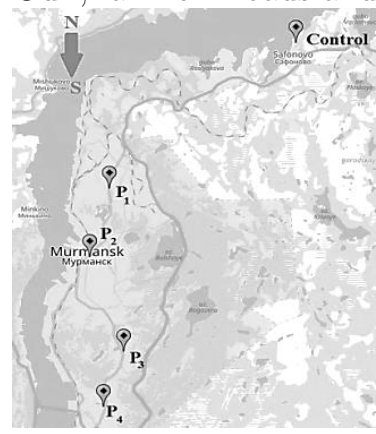

Figure 1. Experimental plots in cenopopulations of $S$. josikaea in the territory of the city of Murmansk: Control control site in Safonovo village; $\mathrm{P}_{1}$ - square near the shopping center "Mir"; $\mathrm{P}_{2}$ - square in the Leningradskaya Street; $\mathrm{P}_{3}$ - square near the stop "Autopark"; $\mathrm{P}_{4}$ - square at the Shevchenko Street 
According to the results of climate monitoring, it is shown that in all parts of the city the warmest month is July, the coldest months are January and February [32]. In the northern (Leninsky) and southern (Pervomaisky) districts, the winter is colder than that in the center of Murmansk (Oktyabrsky district), which is located closer to the Kola Bay of the Barents Sea. Night frosts in the city in August are not observed, but on the southern outskirts are possible [32]. In Murmansk, there is only one weather station, so there is no data on temperature differences in the city's districts.

\subsection{Morpho-physiological Analysis}

On each experimental site 10 shrubs of S. josikaea was marked. In order to study the dynamics of the floral organogenesis of the Hungarian lilac, in December 2014 and May 2015 (before the beginning of bud opening), samples of buds were formed on each experimental plot and in the control. The collection of apical buds was carried out on 10 bushes of lilac ( 5 buds per plant), total volume of each sample $\mathrm{N}=$ 50. The material was fixed in $50 \%$ ethyl alcohol. During the morpho-physiological analysis the following indicators were studied: the length of the primordial inflorescence, the number of primordiums of flowers at various stages of organogenesis, the total number of flowers in the inflorescence. The following stages of organogenesis were distinguished: the appearance of the primordial axes of the inflorescence of the first and second order; formation of flowers tubercles; the formation of primordiums of sepals, petals; stamens; carpels, "formed flowers". Studies of floral organogenesis of S.josikaea were carried out with the help of light stereo microscope SM XX Carl Zeiss Jena at magnifications 62 and 100 times. In each sample 30 buds were investigated. The length of the primordial inflorescences was measured with an ocular micrometer. The data were processed using the method of single-factor analysis of variance, the results were considered reliable at $\mathrm{p} \leqslant 0.05$. Microphotographs were performed using a small format CCD camera, which was installed on the ocular tube.

\section{Presentation and Interpretation of Data}

\subsection{Floral Organogenesis}

Researches have shown that the organogenesis of $S$. josikaea flowers begins with the formation of the flower tubercle by apical meristem, then starts the differentiation of calyx and the formation of four sepals in orthogonal position (Fig. 2). In the process of differentiation, the corolla appears as a round elongated structure, along the outer edges of which are formed 4 petals rudiments.

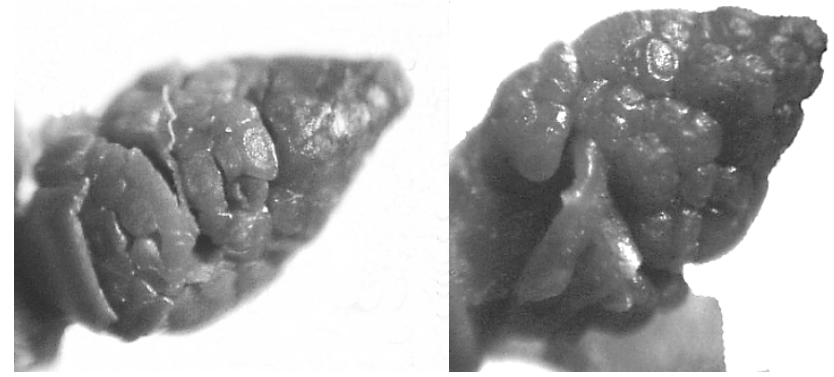

(on the left - December 2014, on the right - May 2015, magnifications 40 times)

Figure 2. The formation of sepals of Syringa josikaea Jacq.

The formation of the androecium begins with the initiation of two primordiums of stamens (Fig. 3), they are not yet differentiated into staminal threads and anthers, in longitudinal section - they are cylindrical structures and consist of meristematic cells. The bicarpillate gynoecium is formed last during the organogenesis of the S. josikaea flower.

As a result of morpho-physiological studies of December samples of S. josikaea buds of the different experimental plots of Murmansk, the presence of primordiums of inflorescences, differing on the level of organogenesis (Fig. 4, Table 1) was revealed. 

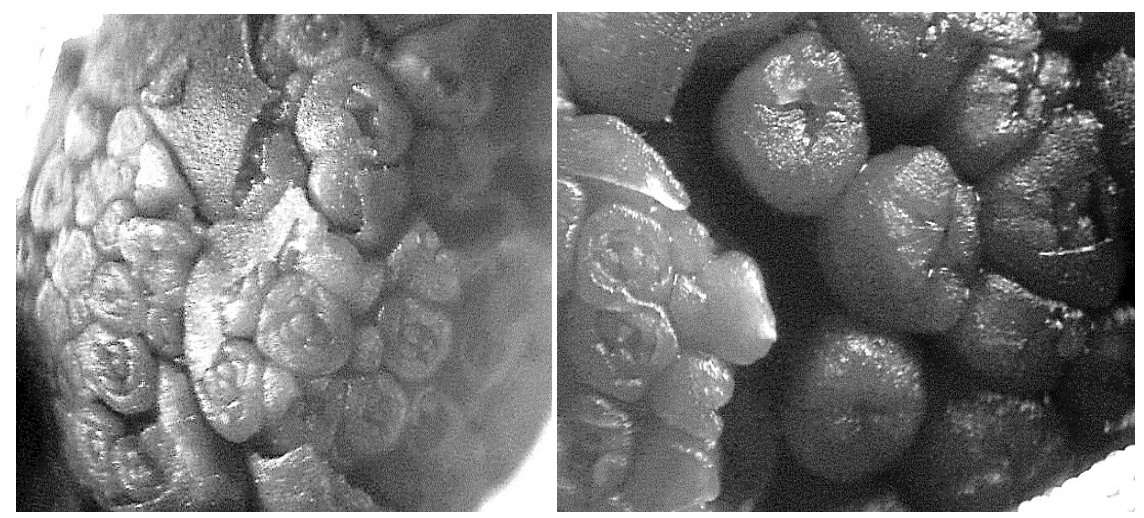

(on the left - December 2014, on the right - May 2015, magnifications 40 times)

Figure 3. The formation of stamens Syringa josikaea Jacq.

Apparently, these are the inflorescences that were formed in summer and passed the differentiation before the entry of $S$. josikaea into a state of winter dormancy [18], which is characteristically for the lilacs [13]. Studies have shown that in the samples of winter buds of S. josikaea from Leningradskaya Street $\left(\mathrm{P}_{2}\right)$ and Shevchenko Street $\left(\mathrm{P}_{4}\right)$, as well as in control, have already formed a large number of primordial flowers (Fig. 4, Table 1) at different stages of organogenesis.

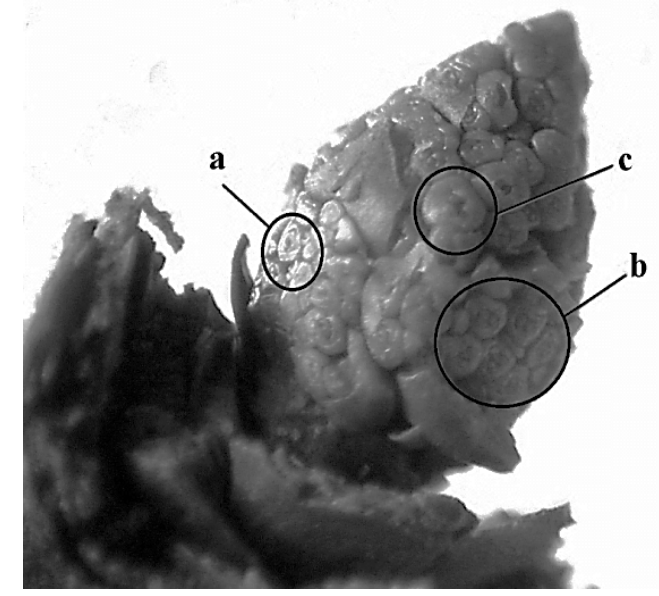

$\mathrm{a}$ - the formation of sepals; $\mathrm{b}$ - the formation of stamens; $\mathrm{c}$-formed flower

Figure 4. The Syringa josikaea Jacq. inflorescence with flowers primordiums at different stages of organogenesis (December 2014)

In these samples, the share of flowers, in which the primordiums of sepals (Fig. 2), the tubercles of stamens and carpels are formed, is high (Fig. 3), and there are also well differentiated flowers (Table 1). The stage of appearance of sepals noted in $30 \%$ of the flowers in sample of the experimental site $\mathrm{P}_{2}, 23 \%$ on the $\mathrm{P}_{4}$, which is higher than in the control $(18 \%)$. On the site $\mathrm{P}_{4}$, the proportion of flowers, having tubercles of stamens make up $39 \%$, on $\mathrm{P}_{2}-16.4 \%$. The most differentiated inflorescences of lilacs - in the center of the city of Murmansk $\left(\mathrm{P}_{2}\right), 26 \%$ of them have "formed flowers", in the control $-27 \%$. In the buds of S.josikaea, collected in December on the experimental sites $\mathrm{P}_{1}$ and $\mathrm{P}_{3}$, primordial inflorescences significantly behind the level of differentiation of the control ones. Axes of inflorescences are poorly developed, the flowers are in the early stages of organogenesis, represented mainly by flower tubercles, primordiums of sepals and petals (Table 1). In sample of the plot $\mathrm{P}_{1}-33 \%$ of the flowers have primordiums of sepals, while in the $\mathrm{P}_{3}-40 \%$. The average number of primordiums of flowers in the inflorescences of lilac in the sample of experimental plot $\mathrm{P}_{1}$ in five times, $\mathrm{P}_{3}-$ three times less than in the control (Table 1). 
Table 1. Average indices (number per inflorescence) of the number of primordiums of flowers in the inflorescence of Syringa josikaea at the different stages of organogenesis (Murmansk, December 2014)

\begin{tabular}{cccccccc}
\hline $\begin{array}{c}\text { Experimental } \\
\text { sites }\end{array}$ & $\begin{array}{c}\text { Flowers } \\
\text { tubercle }\end{array}$ & $\begin{array}{c}\text { Sepals } \\
\text { primordiums }\end{array}$ & $\begin{array}{c}\text { Petals } \\
\text { primordiums }\end{array}$ & $\begin{array}{c}\text { Stamens } \\
\text { primordiums }\end{array}$ & $\begin{array}{c}\text { Carpels } \\
\text { primordiums }\end{array}$ & $\begin{array}{c}\text { Formed } \\
\text { flower }\end{array}$ & $\begin{array}{c}\text { Total } \\
\text { number of } \\
\text { flowers }\end{array}$ \\
\hline Control & 0 & $20,5 \pm 9,0$ & $19,1 \pm 8,2$ & $32,2 \pm 7,8$ & $18,3 \pm 4,9$ & $28,3 \pm 8,4$ & $118,4 \pm 5,5$ \\
$\mathrm{P}_{1}$ & $0,8 \pm 0,8$ & $7,5 \pm 3,0$ & 0 & $7,1 \pm 3,6$ & $3,0 \pm 3,0$ & 0 & $23,0 \pm 9,8$ \\
$\mathrm{P}_{2}$ & $28,8 \pm 12,3$ & $54,9 \pm 14,7$ & $4,7 \pm 3,4$ & $24,8 \pm 12,4$ & $4,0 \pm 2,6$ & $35,1 \pm 22,4$ & $152,4 \pm 21,9$ \\
$\mathrm{P}_{3}$ & $18,5 \pm 9,9$ & $15,1 \pm 8,8$ & $2,1 \pm 2,1$ & $1,0 \pm 0,6$ & 0 & 0 & $36,7 \pm 14,0$ \\
$\mathrm{P}_{4}$ & $13,6 \pm 5,6$ & $39,2 \pm 11,5$ & $24,3 \pm 7,3$ & $64,3 \pm 16,8$ & $23,1 \pm 12,5$ & $3,4 \pm 3,4$ & $167,9 \pm 19,4$ \\
\hline
\end{tabular}

Morpho-physiological studies of spring samples of $S$. josikaea buds revealed an unexpected result. In the May samples from the sites $\mathrm{PP}_{1}, \mathrm{PP}_{3}$, where in the winter were weak differentiation of inflorescences and minimum the total number of primordially flowers (per inflorescence) of the early stages of organogenesis, in the spring were found high differentiated flowers. All flowers in the inflorescences reached the late stages of organogenesis and their total number increased 5 times, compared with the December samples (Table 2, Fig. 5). On an experimental site $\mathrm{P}_{3}$ inflorescences and flowers are completely formed on $100 \%$, in control $-73 \%$.

Table 2. Average indices of the number of flowers primordiums in the inflorescence of Syringa josikaea in Murmansk at different stages of organogenesis in December 2015 (number per inflorescence)

\begin{tabular}{llllllll}
\hline $\begin{array}{l}\text { Experimental } \\
\text { Sites }\end{array}$ & $\begin{array}{l}\text { Flowers } \\
\text { tubercle }\end{array}$ & $\begin{array}{l}\text { Sepals } \\
\text { primordiums }\end{array}$ & $\begin{array}{l}\text { Petals } \\
\text { primordiums }\end{array}$ & $\begin{array}{l}\text { Stamens } \\
\text { primordiums }\end{array}$ & $\begin{array}{l}\text { Carpels } \\
\text { primordiums }\end{array}$ & $\begin{array}{l}\text { Formed } \\
\text { flower }\end{array}$ & $\begin{array}{l}\text { Total number of } \\
\text { flowers }\end{array}$ \\
\hline Control & 0 & $10,8 \pm 6,5$ & 0 & $13,2 \pm 7,8$ & $1,0 \pm 0,4$ & $70,2 \pm 21,9$ & $95,2 \pm 23,0$ \\
$\mathrm{P}_{1}$ & $6,0 \pm 2,1$ & $40,9 \pm 8,0$ & $3,6 \pm 2,5$ & $63,9 \pm 14,2$ & 0 & $13,5 \pm 6,0$ & $128,1 \pm 16,9$ \\
$\mathrm{P}_{2}$ & 0 & 0 & $3,0 \pm 1,6$ & $80 \pm 19,9$ & $2,4 \pm 0,9$ & $4,2 \pm 1,6$ & $89,6 \pm 21,3$ \\
$\mathrm{P}_{3}$ & 0 & 0 & 0 & 0 & 0 & $194,0 \pm 19,9$ & $194,0 \pm 19,9$ \\
$\mathrm{P}_{4}$ & 0 & $26,9 \pm 15,1$ & 0 & $56,0 \pm 16,4$ & $4,2 \pm 2,2$ & $66,0 \pm 20,9$ & $153,1 \pm 18,0$ \\
\hline
\end{tabular}
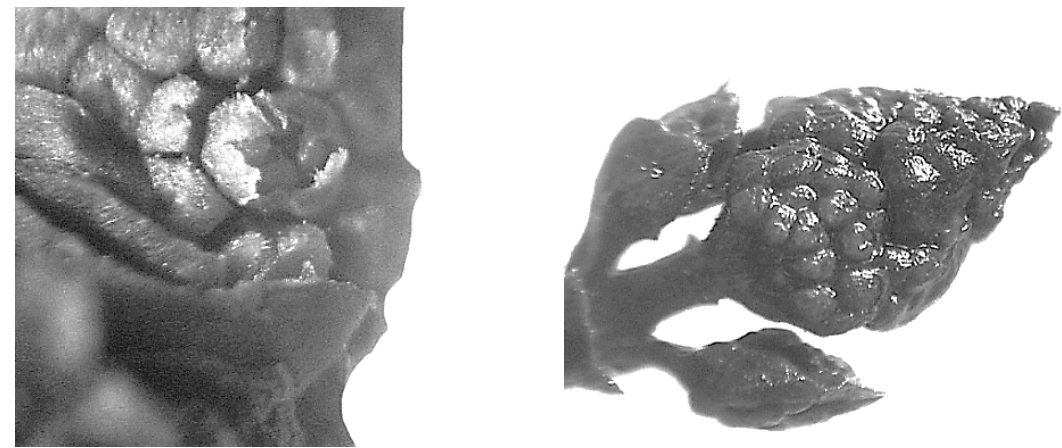

Figure 5. Formed flowers of Syringa josikaea Jacq. (on the left -December 2014, magnifications 40 times; on the right - May 2015, magnifications 25 times)

This fact confirms the data, that generative buds of S. josikaea, unlike S. vulgaris, are differentiated both in the year preceding flowering, and during the year when flowering occurs [22]. Moreover, as shown by the present studies, in the conditions of the Arctic climate of Murmansk, in the spring, after plants leave the state of winter dormancy, floral organogenesis of Hungarian lilac can occur very intensively.

\subsection{Inflorescence Parameters}


During the study, measurements of the length of embryonic inflorescences were taken. It is received, that in the December samples of the buds from the experimental sites of the city of Murmansk, the length of the embryonic inflorescences varies within the limits of $500-2200 \mu \mathrm{m}$ (Table 3: Fig. 6) and statistically significantly differ $(\mathrm{tf}=3,3-7.4$ at $\mathrm{tKr}=2.76, \mathrm{p} \leqslant 0.05)$ from the length of the inflorescences $(1300-4000 \mu \mathrm{m})$ in the spring period in the samples of the control, experimental sites "Mir" $\left(\mathrm{PP}_{1}\right)$ and "Autopark" $\left(\mathrm{PP}_{3}\right)$. Received data indicate, that in conditions of the Atlantic - Arctic climate, in the spring period it is intensive growth of embryonic inflorescences of Hungary lilac, which increase significantly in sizes. In addition, the differences in the size of inflorescences in the city districts in winter were significantly $(p \leqslant 0.05)$, the dimensions of the control differ from results, received in the experimental plots $\mathrm{P}_{1}$ and $\mathrm{P}_{4}$. In the spring, these differences were leveled (Table 3: Fig.6).

Table 3. The length of primordial inflorescences of Syringa josikaea in Murmansk (in $\mu \mathrm{m}$ )

\begin{tabular}{cccccc}
\hline Period & Control & $\mathrm{P}_{1}$ & $\mathrm{P}_{2}$ & $\mathrm{P}_{3}$ & $\mathrm{P}_{4}$ \\
\hline December 2014 & $1100 \pm 100$ & $500 \pm 100$ & $2100 \pm 500$ & $900 \pm 100$ & $2200 \pm 200$ \\
May 2015 & $3000 \pm 600$ & $2300 \pm 200$ & $1300 \pm 100$ & $4000 \pm 400$ & $3100 \pm 500$ \\
\hline
\end{tabular}

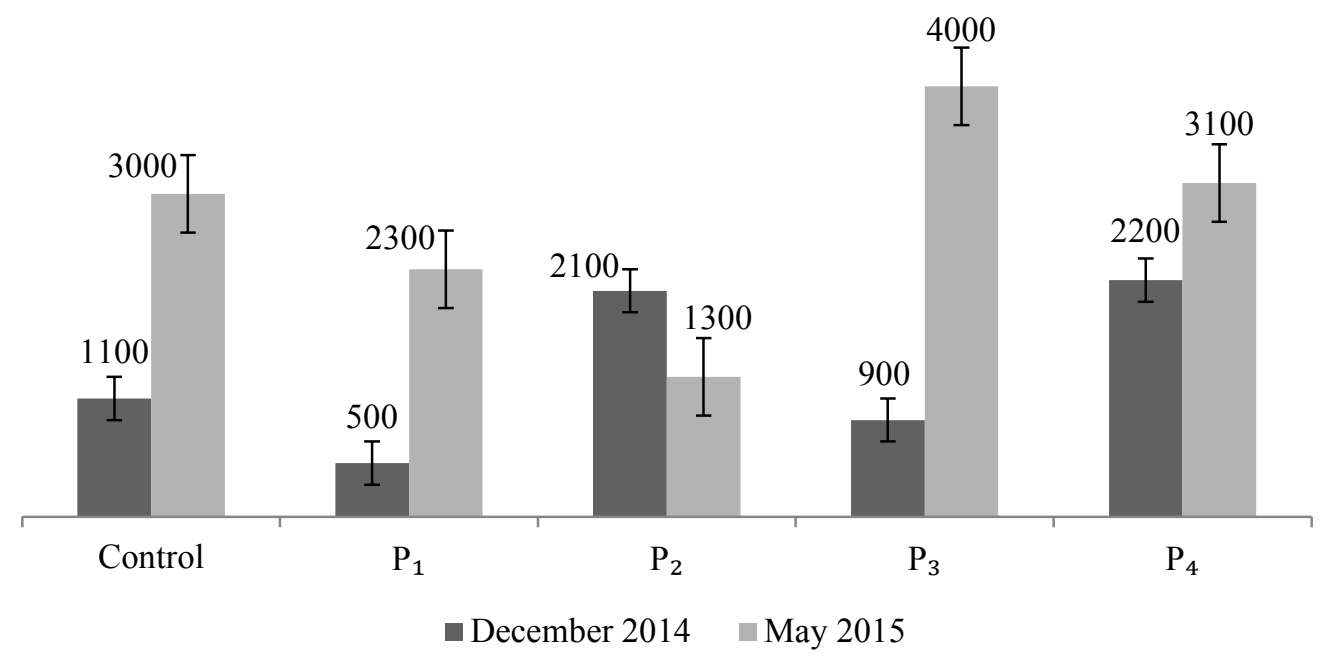

Figure 6. The length of primordial inflorescences of Syringa josikaea in Murmansk (in $\mu \mathrm{m}$ ) Control - control site in Safonovo village; $\mathrm{P}_{1}$ - square near the shopping center "Mir"; $\mathrm{P}_{2}$ - square in the Leningradskaya Street; $\mathrm{P}_{3}-$ square near the stop "Autopark".; $\mathrm{P}_{4}$ - square at the. Shevchenko Street.

The flowering of the Hungarian lilac at the latitude of Murmansk begins in the first decade of July. In other northern cities of Russia, located at lower latitudes, the blooming of this species is noted in the second half of May up to the middle of June [23], [30]. In Murmansk, in the summer of 2015, S. josikaea began to bloom on 10 - 11 of July practically simultaneously at all experimental sites and in control. However, the end of flowering differed: 18 of July the lilac has finished flowering in control and in the northern part of the city $\left(\mathrm{P}_{1}\right)$, on 20 of July - in the center $\left(\mathrm{P}_{2}\right), 21.07$ on the southern sites of the city $\left(\mathrm{P}_{3}, \mathrm{P}_{4}\right)$. The duration of flowering in control and in the plot $\mathrm{P}_{1}$ was 7 days, $\mathrm{P}_{2}-10$ days, and $\mathrm{P}_{3}, \mathrm{P}_{4}-$ 11 days. Thus, the revealed differences in the dynamic of floral organogenesis of lilacs in different districts of the city of Murmansk did not affect the beginning of flowering, but only its duration.

\section{Discussion}

Data on the beginning of the formation of the primordiums of inflorescences and organogenesis of lilacs flowers differ depending on the species, climatic zone and flowering period [13], [18], [22]. Studies of the floral organogenesis of $S$. vulgaris in the territory of Eastern Europe showed, that primordiums of sepals and petals appear in the middle of July, a year before flowering. Up to the end of October there are 
processes of tissue differentiation, then plants enter a state of winter dormancy [13]. After exiting the deep winter dormancy, the differentiation of sepals and petals continues and is significantly accelerated in March - April [13]. Primordiums of stamens appear in the S. vulgaris flowers in early August of the year, previous to bloom. In middle August, occurs differentiation on staminal threads and anthers. After exiting from the winter dormancy in early March of the next year, begins active differentiation of sporogenous tissue and the formation of maternal cells of microspores, by the end of April pollen grains are fully formed [13]. Primordium of gynoecium in S. vulgaris flowers appears in the middle of August. In September, the carpels are lengthen and meristematic cells are formed [13]. According to Z.S. Luneva [14], the beginning of the formation of the embryonal inflorescences of S. josikaea occurs at the end June, their differentiation lasts for July - September. In Bishkek (Kyrgyzstan) the formation of reproductive buds was noted in the first decade of June. By the end of Junes formed the perianth, in the first decade of August - all organs of flowers in the form of meristematic tubercles. S. josikaea enter into the winter with well developed perianth, primordialy stamens and carpels [22].

Previous research [22] shows that S. josikaea, in contrast to other species of lilacs, has a tendency to increase the period of formation of reproductive organs during two growing seasons. This feature of development explains the long flowering of this species. I. G. Penkina [22] believes, that the genus Syringa L. can be attributed to a group of tree plants, that form the primordiums of reproductive organs in the year, preceding flowering. The author points out, that $S$. josikaea in this case is an exception. Studies, conducted in the Arctic climate of Murmansk, have shown that the tendency for the prolongation of the period of floral organogenesis of Hungarian lilac is further enhanced in high latitudes. A part of embryonal inflorescences and flowers in some cenopopulations of S. josikaea in Murmansk are laid one year before flowering. In this case $S$. josikaea enter into a state of winter dormancy with inflorescences having the primordiums of flowers of different levels of differentiation.

At the same time in another cenopopulations generative buds entry into a state of winter dormancy in the stage of formation of the axes of the inflorescence. The differentiation of the inflorescences axes and the floral organogenesis of $S$. josikaea begin in the spring of the next year, after exiting the state of winter dormancy. This process is so intensive, that for two - three months most of the flowers reach the late stages of organogenesis. This confirms the already known fact that species successfully introduced in the northern latitudes, have a more intensive differentiation of the reproductive organs [22]. Apparently, asynchrony of floral organogenesis of lilacs is a manifestation of the polyvariance of development, when in extreme climatic conditions genetic potential and ecological plasticity of the species is realized. It is known, that $S$. josikaea is a relic species, which grows in natural conditions in Carpathians. Famous Russian botanist V. L. Komarov [15] wrote, that Syringa L. is a genus of the Tertiary period, which was widely distributed in the Old World, during a period of increased geological activity the range of the genus was ousted to the south. According to M. G. Popov [25] species of the genus Syringa L. were growing in preboreal mesothermal forests on the northern outskirts of the Arcto-Tertiary flora, retreating to the south under the influence of the Pleistocene glacier. Phylogeographical and phylogenetic data confirm the resistance of many forest taxa of the Carpathians during quaternary climatic fluctuations, often in several spatially separated regions [20].

\section{Conclusions}

S. josikaea, as a species, formed in the conditions of the continental climate [23], is characterized by high ecological plasticity and resistance. Apparently, S. josikaea has a broad norm of reaction, which makes it possible to successfully not only grow, but also bloom in the conditions of the polar day and low temperatures on the urbanized territories of the Arctic region. This polyvariance of development has already been revealed in Subarctic aboriginal populations of plants, when under the influence of environmental factors, polyvariance of ontogeny is observed, which is manifested in a change of the duration of stages of development, ramification intensity, changes in the time of formation of vegetative and reproductive organs [28]. Data on the polyvariance of the floral organogenesis obtained for the first time for introduced species of woody plants in the conditions of the Arctic city. Results of the research raise a number of questions. In particular, what is the reason for the polyvariance of floral organogenesis of different cenopopulations of $S$. josikaea in Murmansk. It can be assumed that the cause may be a difference in age of the studied green plantations or in microclimatic conditions, etc. To answer these 
questions, are needed further detailed studies of the organogenesis of reproductive organs of woody plants, introduced in urbanized areas of the Euro-Arctic region.

\section{References}

1. N. Balaj, L. Haxhinosto, F. Hasani, I. Lushi, F. Balaj, "The study of flowering shrubs (Forsythia, Syringa, Cotoneaster) cultivars in the environment architecture and urbane landscape" Research Journal of Agricultural Science 44 (2), 145 - 151, 2012

2. C. Brunsdon, L. Comber, "Assessing the changing flowering date of the common lilac in North America: a random coefficient model approach", Geoinformatica 16 (4), 675 - 690, 2012.

3. N. E. Bulygin, "Dendrology" (in Russian) Leningrad. 1991. 352 p.

4. M. Dadpour, S. Naghiloo, S. Peighambardoust, S. Panahirad, M. Aliakbari, A. Movafeghi, "Comparison of floral ontogeny in wild - type and double flowered phenotypes of Syringa vulgaris (Oleaceae)", Scientia Horticulturae 127 (4), 535 - 541, 2011.

5. V. I. Demin, "Evaluation of the role of anthropogenic heat in the problems of diagnostics of climatic changes", in Status and prospects of the development of geophysical studies in high latitudes (in Russian), 168 - 170, 2010.

6. B. Densow, M. Strzalkowska - Abramek, "Characteristics of blooming and pollen in flowers of two Syringa species (f. Oleaceae)", Acta Agrobotanica, 66 (4), 67 - 71, 2013.

7. G. Dihoru, G. Negrean, "The Red Book of Vascular Plants of Romania. Romanian Journal of Biology", 54 (1), 101-114, 2009.

8. A.A. Gerasimova, "Phenological monitoring of tree and shrub vegetation in Tyumen" (in Russian), PhD. biol. sci. diss., Tyumen, 2015.

9. O. B. Gontar, V. K. Zhirov, L. A. Kazakov, E. A. Svyatkovskaya, N. N. Trostenyuk, "Green construction in the cities of the Murmansk region"(in Russian) Apatity, 2010.

10. O. B. Gontar, E. A. Svyatkovskaya, N. N. Trostenyuk, N. M. Korobeinikova, E. P. Shpak, O. Yu. Nosatenko, "Monitoring of the condition of tree plantations on some landscaping objects in the central part of Murmansk city," (in Russian). Proceedings of the Samara Scientific Center of the Russian Academy of Science 15, (3), 621 $625,2013$.

11. O. B. Gontar, E. A. Svyatkovskaya, N. N. Trostenyuk, V. K. Zhirov, "Stages of creation and analysis of the peculiarities of the assortment of ornamental woody plants for optimal landscaping of the urbanized territories of the Far North," (in Russian) Bulletin of the Murmansk State Technical University 14 (3), 577 - 582, 2011.

12. A. Jedrzejuk, A. Lukaszewska, "High temperatures applied at fall forcing disturb ovule development in Syringa vulgaris L. "Mme Florent Stepman," Acta Physiologiae Plantarum 30 (5), 673 - 678, 2008.

13. A. Jedrzejuk, W. Szlachetka, "Development of flower organs in common lilac (Syringa vulgaris L.) cv. Mme Florent Stepman," Acta Biologica Cracoviensia: Seris Botanica 47 (2), 41 - 52, 2005.

14. I. B. Kirina, "Features of the organogenesis in different varieties of honeysuckle," (in Russian) Achievements of science and technology of agroindustrial complex 8. $27-28,2010$.

15. V. L. Komarov, The doctrine of the species in plants. (in Russian) Moscow - Leningrad, 1940.

16. A. Lendvay, A. Pedryc, M. Holm, "Characterization of Nuclear Microsattelite Markers for the Narrow Endemic Syringa josikae Jack. Fil ex Rchb," Notulae Botanicae Horti Arrobotanici cluy - napoka 41 (1),301 - 305, 2013.

17. B. Lendvay, J. W. Kadereit, E. Westerberg, C. Cornejo, A. Pedryc, M. Holm, "Phylogeography of Syringa josikae (Oleaceae): Early Pleistocene divergence from East Asian relatives and survival in small populations in Carpatians" Biological Journal of Linnean Society 119 (3), 689 - 703, 2016.

18. Z. S. Luneva, N. L. Mikhailov, E.A. Sudakova, "Lilac", (in Russian) Moscow, 1989. 256 p.

19. L. G. Martynov, "The introduction of species of the genus Lilac (Syringa) in the conditions of the botanical garden of the subzone of the middle taiga," (in Russian) Proceedings of the Komi Scientific Center of the Ural Branch of the Russian Academy of Science 4, 25 - 31, 2013.

20. P. Mraz, M. Ronikie, "Biogeography of Carpatians: evolutionary and spatial facets of biodiversity," Biological Journal of Linnean Society, 119 (3), 528 - 529, 2016.

21. S. Naghiloo, M. Dadpour, E. Gholamreza, K. Peter, "Comparative study of inflorescence development in Oleaceae." American Journal of Botany 100 (4), 647 - 663, 2013.

22. G. Penkina, "Lilacs in the Chui Valley", (in Russian) Frunze, 1978. 56 p. 
23. N. V. Polyakova, "Biological features of representatives of the genus Syringa L. at introduction in the Bashkir Preduralie", (in Russian) PhD. biol. sci. diss. Ufa. 2010.

24. N. V. Polyakova, V. P. Putenichin. "Blossoming of lilacs in the Bashkir Preduralye," (in Russian) Proceedings of the Samara Scientific Center of the Russian Academy of Science 1 (3), 801 - 803, 2010.

25. M. G. Popov, "Essay of the vegetation and flora of the Carpathians", (in Russian) Moscow, 1949.

26. A. Selenina, N. A. Selenin, M. A. Zakharova, "Adaptation of the stomatal apparatus in poplar balsam (Populus balsamifera L.), lilac Hungarian (Syringa josikaea Jacq. ex Rchb.) and apple Siberian (Malus baccata (L.) Borkh.) to unfavorable urban environment in Krasnoyarsk," (in Russian) Bulletin of the Irkutsk State Agricultural Academy 44, 98 - 105, 2011.

27. G. Su, Y. Cao, C. Li, X. Yu., P. Tu, X. Chai," Photochemical and pharmacological progress on the genus Syringa," Chemistry Central Journal 9 (2), 1 - 12, 2015.

28. N. V. Vasilevskaya, "Polivariance of the ontogenic processes of plants in high latitude conditions", (in Russian) Murmansk, 2007.

29. N. V. Vasilevskaya, D. A. Morozova, "Teratomorphizm of pollen of Syringa josikae Jacq., introduced in the urbanized territories of the Russian Arctic," (in Russian) Proceedings of Petrozavodsk State University. Biological sciences 161 (8), 7 - 13, 2016.

30. A.A. Vidyakina, M. V. Semenova, "Phenological observations of the development of vegetative and generative organs of Syringa josikae Jacq. in various parts of Tyumen," (in Russian) Bulletin of Ecology, Forestry and Landscape. 9, 142 - 145, 2009.

31. H. Wang, Q. Ge, J. Da., Z. Tao, "Geographical pattern in first bloom variability and its relation to temperature sensitivity in the USA and China," International Journal of Biometeorology 59 (8), 961 - 969, 2015.

32. B. A. Yakovlev, "Climate of Murmansk" (in Russian) Leningrad, 1972.

33. S. N. Zhakova, "Reproductive biology of some species and cultivars of the genus Lilac (Syringa L.)". (in Russian) PhD. biol. sci. diss. Perm, 2015.

34. S. N. Zhakova, L. V. Novoselova, "Embyological features of the structure and development of ovules and embryo sacs of some species Syringa L.," (in Russian) Bulletin of the Orenburg State University 9 (184), 101 $107,2015$. 